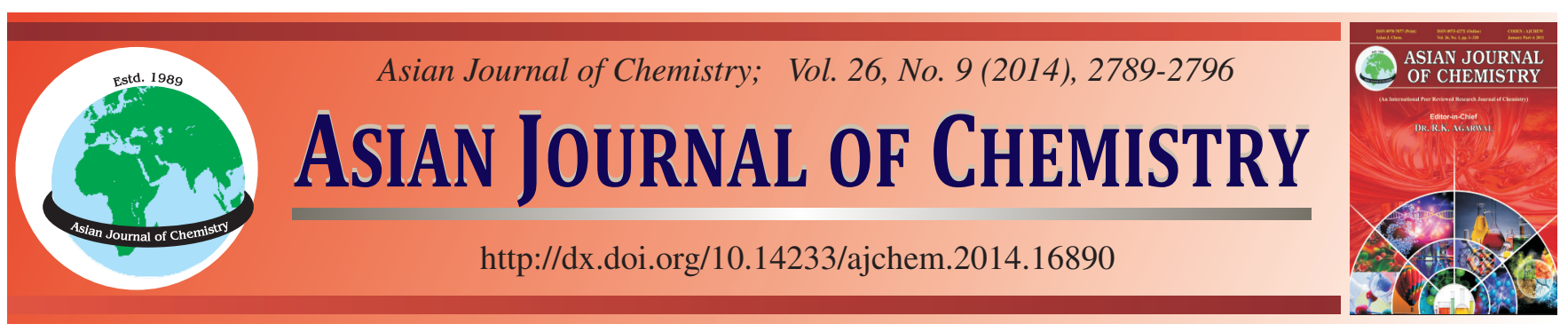

\title{
Quantification of Chemical Weathering and Mass Balance of Soils Developed on Two Different Catena Derived from Granite and Gneiss in Denizli, Turkey
}

\author{
H. SENOL ${ }^{*}, 1$, H.H. OzAYTEKIN ${ }^{2}$ and M. AKGUL ${ }^{1}$
}

${ }^{1}$ Department of Soil Science and Plant Nutrition, Faculty of Agriculture, Suleyman Demirel University, Isparta, Turkey

${ }^{2}$ Department of Soil Science and Plant Nutrition, Faculty of Agriculture, Selcuk University, Konya, Turkey

*Corresponding author: Fax: +90 246 2118696; Tel: +90 246 2118607; E-mail: huseyinsenol@ sdu.edu.tr

\begin{abstract}
Features of pedogenic evolution were detected in mountain soils developed on two different catena from the Buldan horst (Denizli, Turkey). Mass-balance analysis was used to quantify elemental losses, gains and transformations for soil developed on Granite and Gneiss rocks. For these purpose geochemical features, elemental mass-balance change, some physicochemical properties were determined to compare the weathering rates of profiles. These soils are characterized as coarse textured with low organic matter content. Weathering indices such as Chemical Index of Alteration (CIA), Product Index (P), some geochemical rates (Eu/Eu*, $\mathrm{Ce} / \mathrm{Ce}^{*}$, etc.) and other characteristics (physical, chemical, etc.) indicated some pedogenic evolution. These indices indicated that these soils developed have similar pedochemical activity. The dominant duration identified with mass-balance analysis include desilication and loss of bases. This analysis of calculations indicate that in extensive mineral weathering resulted in significant leaching losses of silicon, major base cations and aluminium. A very simple relationship between the site properties and elements losses could be found. This study imply that the rate of elemental massbalance changes is determined by factors influencing its leaching. The results show that the site conditions of soil development have a much greater influence on elemental leaching and weathering than parent material in the soils studied.
\end{abstract}

Keywords: Mass balance, Weathering, Granite, Gneiss.

\section{INTRODUCTION}

Soils play a major role in the biogeochemical cycle including weathering and the storage of nutrients and carbon. The rate of the reactions is of fundamental interest in the understanding of the soil system and its interaction with the surrounding environmental conditions. Rock's chemical weathering is an essential geological process that controls global climate activities by controlling elements' geochemical cycles and modifying the surface of the earth. An understanding of the processes of rock weathering and sediment formation is essential in the study of the evolutionary history of the earth particularly that of the continental crust ${ }^{1,2}$. This in turn requires a sound knowledge of the geochemical behaviour of elements during weathering/soil formation and during the sedimentary redistribution processes under different climatic conditions.

Elemental distribution in soil is determined by several factors including the parent material, leaching and migration of elements from or within the soil profile, biocycling and on additions via atmospheric wet and dry deposition due to natural sources. The soil's initial material is its parent material which fundamentally defines its elemental nature. Weathering is the main cause, which modifies the elemental nature of the soil. The weight of each of these main factors depends on the degree of evolution of the soil (for weakly evolved soils the imprint of the parent material is very important) and the mobility of the specific element in the soil system but it also depends on external factors (land use, vegetation, proximity to pollution sources).

Mineral weathering is an environmentally significant process in soils. For instance, acid rains can be neutralized by dissolution of proton consuming silicate minerals at most ${ }^{3}$, atmospheric $\mathrm{CO}_{2}$ can happen by $\mathrm{Mg}$ and $\mathrm{Ca}$ silicates dissolution, thus dissolution has an important role in shaping the climatic activities ${ }^{4}$. Chemical weathering is a constant and a dynamic geochemical progress in soil minerals that is a surface cations supplier. Therefore weathering is the key element to determine the chemical situation of the soil and availability of plant nutrients in a long time period ${ }^{5}$. Base cation losses from a soil occur through plant uptake and leaching and are replaced by the primary mechanism of soil mineral weathering ${ }^{6}$. Acidification may occur if the weathering rate cannot exceed at least the depletion of the surface cations ${ }^{7,8}$. Lots of efforts have been spent in order to determine these rates. 
Different elements are influenced differently by several pedogenic processes. Primary minerals' dissolution, secondary minerals' formation, carrying over the material, ion interchanges and redox processes are some of these processes. Therefore after weathering the redistribution and mobilization of weathered elements follow different footsteps ${ }^{9}$. Birkeland ${ }^{10}$ proposed that elements released by weathering may or may not be redistributed down-slope as a function of their mobility under constant or changing geochemical environments along the slope. Soil formation in mountainous areas is strongly affected by active geomorphic processes ${ }^{10}$. Where erosion dominates, the majority of soils are formed on fresh colluvial materials or on exposed erosional surfaces ${ }^{11}$. Thus, the central image of soils formed in mountains is a weakly developed profile formed on recent sediments ${ }^{12}$. However, because the time of soil development depends particularly on the slope, aspect and vegetation of the site, soils in mountainous areas are arranged in a kind of mosaic formed by a combination of slope processes and pedogenesis $^{13}$. The change in the balance between erosion and weathering is ascribed to climatic change ${ }^{10}$, land use change ${ }^{14}$, or catastrophic events. A slope is generally dynamic, but there are zones of stability where the rate of pedogenesis is higher than the rate of denudation or accumulation and mature soils do form.

Clear and significant soil maturity stages, it might be also possible to detect durations of soil formation from soil development indices. Within the scientific community this concept is regarded very critically and doubtfully, because the duration of soil formation is not the only factor influencing the soil maturity stage. Differences in parent materials, relief or climatic conditions must be considered too. Chemical weathering index is referred to alternation index sometimes which is used in general for defining weathering profile specifications. These indexes include essential oxide chemistry elements all together into a single value of each sample. These indices are applied in general by graphing some specific indices along with depth in a weathering profile. This plotting provides a representing view of the increasing or decreasing chemical weathering changes of the initial rock. Weathering index changes in terms of depth are steady and systematic, constant and progressive for uniform initial rocks ${ }^{15}$, giving continuous filtration of the elements on a beginning uniform parent material's weathering process. For weathering profile the weathering indexes are calculated institutionally by using the essential element oxides' molecular dimensions. Stoichiometrical changes are shown in the index value which occurs during weathering. The molecular proportion of each oxide is easily calculated from the percentage of the oxide based on weight.

On an initial material after cumulative actions and energy fluxes, the soil comes out. This is a gradual transformation affect (there are other things as well) of initial minerals to secondary components ${ }^{16,17}$. The different factors that modify such fluxes over time are topographic relief, living organisms including humans and the climate. Water-rock interactions, is the loss of alkali and alkaline earth elements followed by silicon, which results in the production of an oxide and oxyhydroxide assemblage consisting of aluminum and iron. This elemental loss sequence is reflected in the typical clay mineral weathering sequence of illite to smectites to kaolinite to gibbsite and iron oxides (oxides and oxyhydroxides of $\mathrm{Fe}$ ).

There are two traditional methods for the measurement of chemical weathering rates. The first by measuring input/ output balances of a basin and the second by analyzing chemical depletion and making reinforcement measurements of the non eroding soils if the age is known. The modern approach depends on mass balance of particles of initial rock and soils. The mean of the weathering rates over a duration scale of pedogenesis, makes it ideal for many studies in terms of water catchment geochemistry, soil improvements and the long term feedbacks between abrasion and climatic conditions. The pedological mass balance (PMB) model ${ }^{18-20}$ is one of the best approaches in quantitative geochemistry in order to estimate chemical weathering and pedogenesis. Within this vertical one dimensional approach for a given element enrichment factor estimations are permitted in a soil layer, depending on changes in 1) density (strain), 2) porosity (residual enrichment) and 3) mass replacement ${ }^{20}$. Since the first two components' occurrence with no movement of the considered element, they represent "closed-system" subscriptions to the inspissations factor. The third component is referred as "open system" subscription, which is a result of net element movements within the soil layer boundaries.

Comprehensive geological studies of weathering processes and products are required to interpret geological formation sequences in a better way and to investigate average crustal composition as a constraint on a model of large scale crustal evolution through geological time $\mathrm{e}^{21-30}$. The objective of this study was to describe an empirical method to model this opensystem contribution based on the analysis of compositional change within soil profiles and to determine the weathering rates of soil developed on a catena with respect to the soil forming factor topography, with some weathering indices using geochemical data in semi-arid environment with similar geological patterns and climate. Mass balance and some weathering indices with other features such as the mineralogy and some analytical characteristics of soil developed on two different catena and parent materials are presented here in order to discuss their use in quantifying the maturity stages and durations of soil formation.

\section{EXPERIMENTAL}

Theoretical background: Time-averaged leaching rates can be calculated if the age of the parent material and the initial volume of the weathered material are known. Comparison of the mineral composition of the soil profiles in a known age and rock compositions as fresh sources determines the long term weathering rates ${ }^{31,32}$. Motionless element contents are used to determine the enrichment and depletion factors, which are also used to make such calculations. Average of motionless elements' concentration profiles such as $\mathrm{Zr}$ or Ti derives weathering rates of the soil compositions in general. This method is used in many investigation fields on silicate host item ${ }^{32-38}$.

By using motionless elements, the mass balance calculations can be made, but two significant assumptions about elemental components must be accepted ${ }^{35}$. The first assumption is about determining the initial material's composition. The potential mistakes are limited to local heterogeneities in base 
rock composition for the soils formed in these base rocks. The approximation of the initial formation becomes harder when soils are developed on residual initial materials. Loess deposits and alluvial terraces are examples of these materials. The least weathering horizon is assumed to be the initial material in the soil profile for these deposits. Weatherable elements should be rationed over a fixed component such as the soil and the parent material. Zirconium and Titanium are considered to be almost immobile. However, some investigations show that, some metals also can be weathered under certain conditions ${ }^{34,39}$. The formations o mass balance equations and the applications to pedologic procedures are addressed in detail ${ }^{18,20,40,41,36}$.

Mass-balance calculations and especially the calculation of time-averaged weathering rates of soil profiles or soil horizons are usually made by the following equations. Volumetric changes that occur during pedogenesis are determined by adopting the classical definition of $\operatorname{strain}^{18}$,

$$
\varepsilon_{\mathrm{i}, \mathrm{w}}=\frac{\Delta \mathrm{z}_{\mathrm{w}}}{\Delta \mathrm{z}-1}
$$

with $\Delta \mathrm{z}$ as the columnar height $(\mathrm{m})$ of a representative elementary volume of proctored ' $\mathrm{p}$ ' and $\Delta \mathrm{z}_{\mathrm{w}}$ is the weathered equivalent height $(\mathrm{m})$ ' $\mathrm{w}$ '. The calculation of the open-system mass transport function $\mathrm{t}$ is defined by Chadwick et al. ${ }^{20}$

$$
\tau_{j, w}=\left(\frac{\rho_{w_{c_{j, w}}}}{\rho_{p_{c_{j, p}}}}\left(\varepsilon_{i, w+1}\right)\right)-1
$$

with $\mathrm{C}_{\mathrm{j}, \mathrm{p}}$ as the concentration of element $\mathrm{j}$ in protolith $(\mathrm{kg} / \mathrm{t})$, $\mathrm{C}_{\mathrm{j} . \mathrm{w}}$ as the concentration of element $\mathrm{j}$ in the weathered product $(\mathrm{kg} / \mathrm{t})$ and with $\rho_{\mathrm{p}}$ and $\rho_{\mathrm{w}}$ being the bulk density $\left(\mathrm{t} / \mathrm{m}^{3}\right)$ of the prolithe and weathered soil, respectively. With $n$ soil layers the calculation of changes in mass of element $\mathrm{j}$ is given by ${ }^{36}$.

$$
\mathrm{m}_{\mathrm{j}, \mathrm{flux}\left(\mathrm{z}_{\mathrm{w}}\right)}=\Sigma_{\mathrm{a}=1}^{\mathrm{n}} \mathrm{C}_{\mathrm{j}, \mathrm{p}} \rho_{\mathrm{p}}\left(\frac{1}{\mathrm{z}_{\mathrm{i}, \mathrm{w}+1}}\right) \tau_{\mathrm{j}, \mathrm{w}} \Delta \mathrm{z}_{\mathrm{w}}
$$

Zirconium was selected as the immobile element for calculating volume changes (strain). Ti and $\mathrm{Zr}$ have been used as immobile indices because they are generally stable in soil environments ${ }^{18-20,40-43}$.

Despite of providing a tool for elemental loss or gain of a soil profile by the above equations, the mass balance equations have many crucial assumptions. The first assumption is that the contents of the elements in rocks and soils must be homogeneous in relative or variation in these is measurable. The copies assist on average and variance of increasing precision approximations. The second assumption is that the reference element should not be effected by chemical dissolution, because the calculations and measurements are significantly based on motionless elemental concentrations ${ }^{37}$.

Calculation of weathering indices and genetic ratios: Several indexes have been defined to characterize chemical weathering in soils $\mathrm{s}^{44,45}$. These indexes are based on the ratio of the surface cations ( $\mathrm{Ca}, \mathrm{Mg}, \mathrm{K}, \mathrm{Na}$ ) to $\mathrm{Al}$ and/or $\mathrm{Si}$ and the specifications of these indices are a like in general. This studied were used the weathering indices for the quantification of chemical weathering intensity such as Chemical Index of Alteration $(\mathrm{CIA})^{45}$ and Product Index $(\mathrm{P})^{46}$. In the equations,
$\mathrm{CaO}^{*}$ is associated with the silicate fraction and corrected for inputs from carbonate and apatite $\mathrm{CaO}^{*}$ is dependent on assuming the molar $\mathrm{CaO} / \mathrm{Na}_{2} \mathrm{O}$ ratio of silicates cannot exceed one. If the molar $\mathrm{CaO}$ content is not equal or higher than the molar value of $\mathrm{Na}_{2} \mathrm{O}$ content, this value is referred as $\mathrm{CaO}^{*}$. For other situations, as an assumption the molar value of $\mathrm{Na}_{2} \mathrm{O}$ content is equal to the $\mathrm{CaO}$ content of silicates ${ }^{47}$. In this study, apatite $\left[\mathrm{Ca}_{5}\left(\mathrm{PO}_{4}\right)_{3}\right]$ correction was also made by assuming that all measured $\mathrm{P}_{2} \mathrm{O}_{5}$ was from apatite and calculating the amount of $\mathrm{Ca}$ associated with it. Besides some geochemical ratios and $\mathrm{Ce}$ and $\mathrm{Eu}$ anomalies were used to quantification of weathering degree of studied profiles. Cerium and europium can occur in different oxidation states and often show greater fractionation relative to the other earth elements. The earth element concentrations are normalized relative to a chondritic reference standard to facilitate the comparison of rare earth element patterns between sites. As the proposition of ${ }^{48}$; Eu's measured concentration is compared with Eu's expected concentration in order to estimate the europium anomalies, which is achieved by interpolation between normalized values of $\mathrm{Gd}$ and $\mathrm{Sm}$. Eu anomalies can be calculated as follow;

$$
\mathrm{Eu} / \mathrm{Eu}^{*}=\mathrm{EuN} / \sqrt{ }(\mathrm{Sm})_{\mathrm{N}} \times(\mathrm{Gd})_{\mathrm{N}}
$$

Cerium anomalies are estimated by comparing the measured concentration of $\mathrm{Ce}$ with an expected concentration of $\mathrm{Ce}^{*}$ obtained by interpolation between the normalized values of La and Pr. Cerium anomalies can be calculated as follow;

$$
\mathrm{Ce} / \mathrm{Ce}^{*}=\mathrm{Ce}_{\mathrm{N}} / \sqrt{ }(\mathrm{La})_{\mathrm{N}} \times(\mathrm{Pr})_{\mathrm{N}}
$$

Site description and geological setting: The fields were located in Buldan (Denizli) district in Turkey. In Buldan, the mean annual temperature is $16.2{ }^{\circ} \mathrm{C}$ and annual rainfall $547.1 \mathrm{~mm}$, fourth occurring during the warm season ${ }^{49}$ (July to September). Soil temperature regime is thermic and soil moisture regime is xeric ${ }^{50}$.

In the study area, the oldest unit is Precambrian Çine formation, including migmatitic pelitic gneiss, augen gneisses, banded gneisses and Ordovician metagranites containing mafic microgranular enclave with sharp contact. It was overlied by Paleozoic Ortaköy formation, which is composed of garnetmica schists, with amphibolites, quarzite and marbles bands and/or lenses. Lower Miocene Gencelidere Granite is intrusive into the Ortaköy formation and overlied by lower Pliocene Kolonkaya formation including sandstones interbanded with claystone, siltstone, limestone and marl. All units were covered by Pleistocene Asartepe formation, which include irregular alternation of conglomerate, sandstone, siltstones and mudstone and quaternary alluvium unit ${ }^{51}$.

Sampling and analysis: For the study, six representative soil profiles were chosen and soil samples were taken from the horizons after their macro morphological identification was completed. Soil samples were oven dried at $40{ }^{\circ} \mathrm{C}$, ground and sieved to obtain the $<2 \mathrm{~mm}$ fraction. The calcimeter method (lime) $)^{52,53}$ was used to measure the carbonate concentration in the soil. Organic matter (SOM) was determined by a modification of the Walkley and Black's titration method as outlined by Nelson and Sommers ${ }^{53}$. Soil $\mathrm{pH}$ was measured potentiometrically, in a 1:1 soil/water (w/v) suspension with a glass electrode ${ }^{54}$. Electrical conductivity (EC) was determined potentiometrically in a 1:1 soil water suspension using a glass electrode $^{54}$. Particle size distribution was determined by the 
hydrometer method after removal of organic matter using $\mathrm{H}_{2} \mathrm{O}_{2}$ and stirring in a sodium hexametaphosphate solution ${ }^{55}$.

Total elemental analysis of the soil samples was conducted through fusion with lithium metaborate $\left(\mathrm{LiBO}_{2}\right)$ and dilution in a $\mathrm{HNO}_{3}-\mathrm{HF}$ solution according to the procedure outlined by Chao and Sanzolone ${ }^{56}$, samples were taken into solution by alkaline fusion using a mixture of $0.25 \mathrm{~g}$ soil powder and $0.75 \mathrm{~g}$ flux (lithium tetra metaborate). $0.2 \mathrm{~N} \mathrm{HNO}_{3}$ solutions diluted to 1:1000. An aliquot of the sample solution was analyzed for the trace element and rare earth element, on a combination simultaneous/sequential (ICP-MS). Detection limits were 0.002 to $0.01 \mathrm{ppm}$ for all major elements and 0.1 to $1 \mathrm{ppm}$ for all trace elements. The instrument was calibrated using certified standard reference materials (SO-18/CSC) and then the contents were measured by inductively coupled argon plasma.

\section{RESULTS AND DISCUSSION}

Physical, chemical properties and total contents: In this study area altitude is generally less than $1180 \mathrm{~m}$ asl and slopes do not exceed $2 \%$. Four profiles were studied in detail in order to mass balance and chemical weathering of soil. These profiles are developed in granite and gneiss of parent materials. However, the composition of the investigated material clearly reflects its granitic character. The range of descriptive soil parameters are: $\mathrm{pH} 4$.94-7.89, EC 24.7-282 $\mu \mathrm{S} / \mathrm{cm}$, lime equivalent 0.36-1.77 \%, organic matter 0.07-2.85\%, clay 2.01-15.29\%, silt 7.54-35-14\% sand 56.23-82.54\%. Soils are generally loamy sand to sandy loamy in texture and have abundant coarse fragments of all sizes. Typically, soils studied exhibit A1, AC and $\mathrm{C} / \mathrm{Cr}$ horizonation.

Concentrations of the measured elemental oxides are shown in Table-1. All soils contained much $\mathrm{SiO}_{2}, \mathrm{Al}_{2} \mathrm{O}_{3}$ and low $\mathrm{Fe}_{2} \mathrm{O}_{3}$ and $\mathrm{MgO}$. The $\mathrm{SiO}_{2}$ concentration rose to $72.88 \%$. $\mathrm{Al}_{2} \mathrm{O}_{3}$ values ranged from 13.33 to $17.14 \%$ and tended to increase with depth. The highest $\mathrm{Fe}_{2} \mathrm{O}_{3}$ value was observed in profile 59 as $7.16 \%$. $\mathrm{CaO}$ values were higher in the surface than the subsoil in all profiles except profile ${ }^{59} . \mathrm{MgO}$ values ranged from 0.64 to $3.44 \%$ and showed no important diffe- rences among the horizons. The small amount of $\mathrm{MgO}$ was due to the small amount of biotite. Al concentration correlated with clay distribution in the soils. In the studied soils, $\mathrm{Al}_{2} \mathrm{O}_{3}$ values were similar in solum and parent material as a result of the low weathering rate. $\mathrm{K}_{2} \mathrm{O}$ and $\mathrm{Na}_{2} \mathrm{O}$ values ranged from 1.18 to $5.86 \%$ and from 2.30 to $6.75 \%$, respectively. $\mathrm{K}_{2} \mathrm{O}$ values correlated with the presence of $\mathrm{K}$-feldspar, one of the most common mineral in granitic rock.

Weathering indices, genetic ratios and anomalies: Some weathering rates, genetic rates and $\mathrm{Eu}$ and $\mathrm{Ce}$ anomalies are shown in Table-2. In the profiles, the CIA rate varied between 55.33 and 59.17 and no significant difference was found between the profiles. The CIA values were not shown any regular differentiation trend with depth in profiles the variation in the $\mathrm{P}$ values between the profiles was also limited. The $\mathrm{P}$ values ranged between 83.23 and 88.46 and no trend was found with depth in the profiles.

The $\mathrm{Ce}$ and Eu anomalies, which are indicators of weathering and oxidation conditions in soils, showed a homogenous distribution and no significant differentiations were found between values ${ }^{57}$. While negative Eu anomalies were found in the all soils, a weak positive $\mathrm{Ce}$ anomaly was found in profiles 3 and 49 in some horizons. In the soils studied the Eu and Ce anomalies ranged between $0.30-0.75$ and 0.88-1.14, respectively. Among the geochemical rates calculated to determine weathering and enrichment-depletion rates, the Th/ $\mathrm{U}$ value ranged between 0.27 and 1.94. The highest values were found at upper horizons generally. The lowest value was seen in profile 49 in horizon $\mathrm{C}$. The $\mathrm{La} / \mathrm{Lu}$ rate is an important indicator used in weathering and provenance studies in soils. This value show significant variation in profiles classified in different parent materials and ranged between 2.16 and 12.28. The change curve of the $\mathrm{La} / \mathrm{Nb}$ and $\mathrm{La} / \mathrm{Sm}$ values between soils, an important indicator of LREE, HREE enrichment and, in turn, clay movement in soils, had different distribution trend. These rates ranged between 2.03-11.19 and 2.08-5.90, respectively.

Mass balance calculations: collapse, dilatation: The behaviour of seven elements was evaluated for this study and

\begin{tabular}{|c|c|c|c|c|c|c|c|c|c|c|c|c|c|c|c|c|c|c|}
\hline \multicolumn{19}{|c|}{$\begin{array}{c}\text { TABLE-1 } \\
\text { TOTAL ELEMENT ANALYSIS OF SOIL PROFIT }\end{array}$} \\
\hline \multirow{2}{*}{$\begin{array}{l}\text { Geologic } \\
\text { Units }\end{array}$} & \multirow{2}{*}{ Profile } & \multirow{2}{*}{$\begin{array}{l}\text { Hori } \\
\text { zon }\end{array}$} & \multirow{2}{*}{$\begin{array}{l}\text { Depth } \\
(\mathrm{cm})\end{array}$} & $\mathrm{SiO}_{2}$ & $\mathrm{Al}_{2} \mathrm{O}_{3}$ & $\mathrm{Fe}_{2} \mathrm{O}_{3}$ & $\mathrm{MgO}$ & $\mathrm{CaO}$ & $\mathrm{Na}_{2} \mathrm{O}$ & $\mathrm{K}_{2} \mathrm{O}$ & $\mathrm{TiO}_{2}$ & $\mathrm{P}_{2} \mathrm{O}_{5}$ & $\mathrm{MnO}$ & $\mathrm{Cr}_{2} \mathrm{O}_{3}$ & $\mathrm{Ni}$ & $\mathrm{Sc}$ & $\mathrm{LOI}^{1}$ & SUM $^{2}$ \\
\hline & & & & \multicolumn{11}{|c|}{$(\%)$} & \multicolumn{2}{|c|}{ (ppm) } & \multicolumn{2}{|c|}{$(\%)$} \\
\hline \multirow{9}{*}{$\frac{\mathscr{\Omega}}{\sum_{0}^{\infty}}$} & \multirow{3}{*}{3} & A1 & $0-11$ & 68.79 & 13.88 & 3.09 & 1.08 & 0.58 & 2.52 & 4.27 & 0.45 & 0.08 & 0.06 & 0.00 & 13.00 & 6.00 & 5.00 & 99.80 \\
\hline & & $\mathrm{AC}$ & $11-60$ & 71.54 & 13.52 & 2.85 & 0.96 & 0.46 & 2.50 & 4.53 & 0.42 & 0.07 & 0.04 & 0.00 & 15.00 & 6.00 & 2.90 & 99.79 \\
\hline & & $\mathrm{C}$ & $60-95$ & 68.87 & 14.23 & 3.70 & 1.60 & 0.77 & 2.71 & 4.14 & 0.63 & 0.10 & 0.03 & 0.01 & 25.00 & 8.00 & 3.00 & 99.78 \\
\hline & \multirow{3}{*}{47} & A1 & $0-5$ & 69.46 & 13.95 & 3.80 & 1.54 & 0.60 & 3.57 & 3.18 & 0.61 & 0.19 & 0.03 & 0.01 & 32.00 & 10.00 & 3.00 & 99.94 \\
\hline & & $\mathrm{AC}$ & $5-71$ & 71.42 & 13.33 & 3.29 & 1.37 & 0.57 & 3.73 & 3.06 & 0.53 & 0.17 & 0.03 & 0.01 & 16.00 & 9.00 & 2.30 & 99.81 \\
\hline & & $\mathrm{Cr}$ & $71-90$ & 67.33 & 14.65 & 4.23 & 1.56 & 0.59 & 3.31 & 3.68 & 0.67 & 0.24 & 0.04 & 0.01 & 16.00 & 12.00 & 3.60 & 99.91 \\
\hline & \multirow{3}{*}{60} & A1 & $0-10$ & 70.61 & 14.35 & 1.78 & 1.08 & 0.88 & 5.18 & 1.26 & 0.57 & 0.20 & 0.02 & 0.01 & 5.00 & 8.00 & 3.90 & 99.83 \\
\hline & & $\mathrm{AC}$ & $10-40$ & 71.14 & 15.19 & 1.83 & 1.21 & 0.80 & 5.29 & 1.42 & 0.55 & 0.20 & 0.01 & 0.01 & 10.00 & 10.00 & 2.20 & 99.84 \\
\hline & & $\mathrm{C}$ & $40-85$ & 72.88 & 14.41 & 1.70 & 1.14 & 0.76 & 5.07 & 1.18 & 0.56 & 0.18 & 0.01 & 0.00 & 6.00 & 8.00 & 2.10 & 99.99 \\
\hline \multirow{8}{*}{ 荘 } & \multirow{3}{*}{49} & A1 & $0-9$ & 66.84 & 14.94 & 2.37 & 0.64 & 0.50 & 4.80 & 3.00 & 0.45 & 0.11 & 0.03 & 0.00 & 5.00 & 7.00 & 6.10 & 99.79 \\
\hline & & $\mathrm{AC}$ & $9-28$ & 67.79 & 16.37 & 2.53 & 1.23 & 0.26 & 6.75 & 1.91 & 0.48 & 0.09 & 0.01 & 0.00 & 10.00 & 10.00 & 2.40 & 99.82 \\
\hline & & $\mathrm{C}$ & $28-72$ & 69.13 & 15.86 & 2.76 & 0.89 & 0.27 & 4.72 & 2.64 & 0.41 & 0.08 & 0.01 & 0.00 & 17.00 & 8.00 & 3.20 & 99.97 \\
\hline & \multirow{2}{*}{52} & A1 & $0-15$ & 61.46 & 17.14 & 3.56 & 1.10 & 0.88 & 2.35 & 5.86 & 0.62 & 0.27 & 0.08 & 0.01 & 19.00 & 13.00 & 6.50 & 99.83 \\
\hline & & $\mathrm{Cr}$ & $60-80$ & 66.37 & 15.46 & 3.84 & 1.13 & 0.42 & 2.47 & 5.81 & 0.35 & 0.27 & 0.11 & 0.00 & 24.00 & 8.00 & 3.50 & 99.73 \\
\hline & \multirow{3}{*}{59} & A1 & $0-12$ & 61.99 & 14.49 & 6.86 & 3.44 & 2.17 & 2.60 & 2.30 & 0.92 & 0.25 & 0.08 & 0.02 & 68.00 & 17.00 & 4.80 & 99.92 \\
\hline & & $\mathrm{AC}$ & $12-60$ & 59.58 & 14.71 & 7.10 & 3.60 & 2.37 & 2.61 & 2.34 & 0.92 & 0.24 & 0.07 & 0.02 & 81.00 & 18.00 & 6.20 & 99.78 \\
\hline & & $\mathrm{C}$ & $60-93$ & 60.96 & 14.86 & 7.16 & 3.39 & 2.61 & 2.72 & 2.22 & 0.91 & 0.26 & 0.11 & 0.02 & 71.00 & 19.00 & 4.70 & 99.93 \\
\hline
\end{tabular}

${ }^{1}$ LOI: loss on ignition, ${ }^{2}$ SUM: total 
TABLE-2

WEATHERING INDEX AND SOME GENETIC RATES, Eu AND Ce ANOMALIES OF SOIL PROFILES

\begin{tabular}{cccccccccc}
\hline Profiles & Horizon & CIA & $\mathrm{P}$ & $\mathrm{Th} / \mathrm{U}$ & $\mathrm{La} / \mathrm{Lu}$ & $\mathrm{La} / \mathrm{Yb}$ & $\mathrm{La} / \mathrm{Sm}$ & $\mathrm{Eu} / \mathrm{Eu}$ & $\mathrm{Ce} / \mathrm{Ce}$ \\
\hline \multirow{3}{*}{3} & $\mathrm{~A} 1$ & 58.53 & 87.69 & 0.78 & 6.39 & 6.25 & 3.21 & 0.35 & 1.10 \\
& $\mathrm{AC}$ & 57.81 & 88.46 & 0.78 & 6.65 & 6.27 & 2.92 & 0.31 & 0.93 \\
& $\mathrm{C}$ & 57.88 & 87.07 & 0.72 & 7.28 & 6.73 & 3.50 & 0.35 & 1.06 \\
\hline \multirow{3}{*}{47} & $\mathrm{~A} 1$ & 57.25 & 87.32 & 1.21 & 5.60 & 5.08 & 2.80 & 0.44 & 0.96 \\
& $\mathrm{AC}$ & 55.95 & 88.29 & 1.12 & 6.63 & 6.36 & 3.08 & 0.39 & 0.96 \\
& $\mathrm{Cr}$ & 58.22 & 86.28 & 1.07 & 6.22 & 5.84 & 2.84 & 0.49 & 0.95 \\
\hline \multirow{3}{*}{60} & $\mathrm{~A} 1$ & 55.53 & 88.10 & 1.04 & 3.78 & 3.39 & 2.41 & 0.53 & 0.89 \\
& $\mathrm{AC}$ & 56.49 & 87.64 & 0.83 & 3.80 & 3.39 & 2.08 & 0.51 & 0.91 \\
& $\mathrm{C}$ & 56.70 & 88.43 & 0.90 & 3.18 & 3.11 & 2.39 & 0.62 & 0.94 \\
\hline \multirow{3}{*}{49} & $\mathrm{~A} 1$ & 55.33 & 86.97 & 0.88 & 2.16 & 2.03 & 2.90 & 0.39 & 0.95 \\
& $\mathrm{AC}$ & 54.53 & 86.11 & 0.44 & 3.57 & 3.21 & 2.73 & 0.30 & 1.03 \\
& $\mathrm{C}$ & 58.78 & 86.63 & 0.27 & 6.63 & 5.84 & 3.36 & 0.32 & 1.14 \\
\hline \multirow{3}{*}{52} & $\mathrm{~A} 1$ & 59.17 & 83.80 & 1.50 & 12.28 & 11.19 & 5.90 & 0.54 & 0.88 \\
& $\mathrm{AC}$ & 58.47 & 86.33 & 1.94 & 8.68 & 7.95 & 4.53 & 0.44 & 0.90 \\
& $\mathrm{Cr}$ & 58.14 & 86.01 & 1.93 & 7.95 & 7.24 & 4.66 & 0.47 & 0.88 \\
\hline \multirow{2}{*}{59} & $\mathrm{~A} 1$ & 57.46 & 84.02 & 1.21 & 7.51 & 7.52 & 2.85 & 0.75 & 0.96 \\
& $\mathrm{AC}$ & 56.88 & 83.23 & 1.15 & 7.72 & 7.55 & 2.98 & 0.72 & 0.96 \\
& $\mathrm{C}$ & 56.08 & 83.43 & 1.27 & 6.90 & 6.52 & 2.82 & 0.75 & 0.95 \\
\hline
\end{tabular}

the data for these elements ( $\mathrm{Si}, \mathrm{Al}, \mathrm{Ca}, \mathrm{Mg}, \mathrm{Na}, \mathrm{K}$ and $\mathrm{Fe}$ ) are presented here. These elements were selected because of their abundance in the soils $93 \%$ of total elemental composition expresses as oxides ${ }^{33}$ and their significance in soil formation. Enrichment factor is a ratio of the chemical concentration of an element in the soil to its concentration in the parent material. The mass transport function is defined as the mass fraction of an element added or subtracted from the system during weathering relative to the mass of the element originally present in the parent material. Strain, mass fractions added to or subtracted from each horizon and loss or gain of elements during pedogenesis is calculated according to Eqn. (1)-(3). Chemical composition and bulk density of the parent material were assumed to be best described by the $\mathrm{C}$ horizon of soil profile. Zirconium was selected as the immobile element for calculating volume changes (strain). Zirconium and titanium have been used as immobile indices because they are generally stable in soil environments ${ }^{18-20,40-43}$. The open-system mass transport functions $(\tau)$ are listed against depth for each soil and element in Table-3. Generally, negative values and thus, losses of elements are observed in the profiles except Profile 47and 60. Generally negative strain was found top soil although presence of high organic matter content of top soil. The measured losses along the soil sequence and with respect to the whole soil profile were for $\mathrm{Si}$ in range of 37.40-963.61,

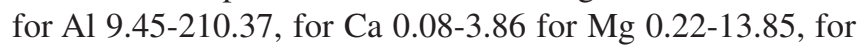

TABLE-3

MASS TRANSPORT FUNCTION VALUES $(\tau)$ AND MASS LOSSES/GAINS $\left(\mathrm{g} / \mathrm{cm}^{2}\right)$ FOR SOME ELEMENTS OF SOIL PROFILES

\begin{tabular}{|c|c|c|c|c|c|c|c|c|c|c|c|c|c|c|c|}
\hline \multirow{2}{*}{ Pedon } & \multirow{2}{*}{$\begin{array}{c}\text { Hori } \\
\text { zon }\end{array}$} & \multicolumn{2}{|c|}{$\mathrm{Si}$} & \multicolumn{2}{|c|}{$\mathrm{Al}$} & \multicolumn{2}{|c|}{$\mathrm{Ca}$} & \multicolumn{2}{|c|}{$\mathrm{Mg}$} & \multicolumn{2}{|c|}{$\mathrm{Na}$} & \multicolumn{2}{|c|}{$\mathrm{K}$} & \multicolumn{2}{|c|}{$\mathrm{Fe}$} \\
\hline & & $(\tau)$ & $\mathbf{M}_{\mathrm{jflux}}$ & $(\tau)$ & $\mathbf{M}_{\text {jflux }}$ & $(\tau)$ & $\mathrm{M}_{\mathrm{jflux}}$ & $(\tau)$ & $\mathbf{M}_{\text {jllux }}$ & $(\tau)$ & $\mathrm{M}_{\mathrm{jflux}}$ & $(\tau)$ & $\mathbf{M}_{\text {jllux }}$ & $(\tau)$ & $\mathrm{M}_{\mathrm{jflux}}$ \\
\hline \multirow{4}{*}{3} & A1 & -0.033 & -3.17 & -0.055 & -1.12 & -0.271 & -0.29 & -0.346 & -0.78 & -0.099 & -0.38 & -0.001 & -0.01 & -0.191 & -1.00 \\
\hline & $\mathrm{AC}$ & -0.111 & -61.77 & -0.187 & -24.42 & -0.489 & -3.46 & -0.487 & -7.15 & -0.211 & -5.24 & -0.064 & -2.42 & -0.341 & -11.58 \\
\hline & $\mathrm{C}$ & 0.000 & 0.000 & 0.000 & 0.00 & 0.000 & 0.00 & 0.000 & 0.00 & 0.000 & 0.00 & 0.000 & 0.00 & 0.000 & 0.00 \\
\hline & Total & - & -64.94 & - & -25.54 & - & -3.75 & - & -7.93 & - & -5.62 & - & -2.43 & - & -12.58 \\
\hline \multirow{3}{*}{47} & A1 & 0.087 & 39.19 & 0.003 & 0.33 & 0.072 & 0.28 & 0.040 & 0.42 & 0.137 & 3.03 & -0.089 & -2.20 & -0.053 & -1.51 \\
\hline & $\mathrm{AC}$ & 0.188 & 35.06 & 0.019 & 0.77 & 0.082 & 0.17 & -0.016 & -0.07 & 0.262 & 2.40 & -0.069 & -0.70 & -0.129 & -1.51 \\
\hline & Total & - & 74.25 & & 1.11 & - & 0.46 & & 0.35 & - & 5.43 & & -2.90 & - & -3.02 \\
\hline \multirow{4}{*}{60} & $\mathrm{~A} 1$ & -0.092 & -10.87 & -0.067 & -1.57 & 0.085 & 0.11 & -0.112 & -0.21 & -0.042 & -0.35 & 0.001 & 0.00 & -0.019 & -0.11 \\
\hline & $\mathrm{AC}$ & -0.085 & -26.54 & 0.116 & 7.19 & 0.115 & 0.37 & 0.124 & 0.61 & 0.105 & 2.28 & 0.274 & 1.39 & 0.140 & 2.22 \\
\hline & $\mathrm{C}$ & 0.000 & 0.000 & 0.000 & 0.00 & 0.000 & 0.00 & 0.000 & 0.00 & 0.000 & 0.00 & 0.000 & 0.00 & 0.000 & 0.00 \\
\hline & Total & - & -37.40 & - & 5.62 & - & 0.48 & - & 0.40 & - & 1.93 & - & 1.39 & - & 2.11 \\
\hline \multirow{3}{*}{49} & A1 & -0.461 & -854.21 & -0.475 & -201.88 & 0.033 & 0.24 & -0.599 & -14.30 & -0.433 & -52.39 & -0.366 & -25.93 & -0.521 & -38.57 \\
\hline & $\mathrm{AC}$ & -0.453 & -109.39 & -0.147 & -8.49 & -0.204 & -0.19 & 0.143 & 0.44 & 0.182 & 3.01 & -0.402 & -3.72 & -0.242 & -2.33 \\
\hline & Total & - & -963.61 & - & -210.37 & - & 0.05 & - & -13.85 & - & -49.38 & - & -29.64 & - & -40.91 \\
\hline \multirow{4}{*}{52} & A1 & -0.547 & -144.53 & -0.458 & -28.18 & 0.025 & 0.04 & -0.524 & -2.36 & -0.535 & -5.26 & -0.507 & -11.72 & -0.547 & -8.36 \\
\hline & $\mathrm{AC}$ & 0.017 & 7.95 & -0.020 & -2.12 & -0.042 & -0.12 & -0.074 & -0.58 & -0.063 & -1.08 & -0.013 & -0.51 & 0.025 & 0.66 \\
\hline & $\mathrm{Cr}$ & 0.000 & 0.000 & 0.000 & 0.00 & 0.000 & 0.00 & 0.000 & 0.00 & 0.000 & 0.00 & 0.000 & 0.00 & 0.000 & 0.00 \\
\hline & Total & - & -136.57 & - & -30.30 & - & -0.08 & - & -2.94 & - & -6.34 & - & -12.23 & - & -7.69 \\
\hline \multirow{4}{*}{59} & A1 & -0.059 & -5.74 & -0.098 & -2.32 & -0.230 & -0.96 & -0.061 & -0.33 & -0.115 & -0.50 & -0.041 & -0.15 & -0.113 & -1.30 \\
\hline & $\mathrm{AC}$ & -0.076 & -36.24 & -0.064 & -7.13 & -0.141 & -2.89 & 0.004 & 0.11 & -0.093 & -1.98 & -0.003 & -0.06 & -0.062 & -3.50 \\
\hline & $\mathrm{C}$ & 0.000 & 0.000 & 0.000 & 0.00 & 0.000 & 0.00 & 0.000 & 0.00 & 0.000 & 0.00 & 0.000 & 0.00 & 0.000 & 0.00 \\
\hline & Total & - & -41.98 & - & -9.45 & - & -3.86 & - & -0.22 & - & -2.48 & - & -0.21 & - & -4.80 \\
\hline
\end{tabular}


$\mathrm{Na}$ 2.48-49.38 for $\mathrm{K}$ 0.21-29.64 for $\mathrm{Fe} 3.02-40.91 \mathrm{~kg} \mathrm{~m}^{-2}$. However for some elements such as $\mathrm{Si}, \mathrm{Al}, \mathrm{Ca}, \mathrm{Mg}, \mathrm{Na}$ and $\mathrm{K}$ slightly gain was found in profile 47 and 60 .

The open system mass transport functions $(\tau)$ were generally high in surface horizons and decrease with depth for the soils developed on granite while high in sub horizons at the Gneiss profiles. The mass transfer profiles indicate that, there is substantial loss of silica from the soils at all depths with the exception of the profile 47. Greater losses of silica occur at the soil surface (up to $30 \%$ ) due to intense weathering and leaching and losses decrease with depth in the granite profiles. The anomalous value in the profiles gneiss top soil is likely due to dust input resulting from atmospheric deposition. However, the positive mass flux of the profile 47 may also be due to the inflow of silica rich water from higher area. All of the soils (except for profile 60) have negative mass flux of $\mathrm{K}$ and the other base cations $(\mathrm{Ca}, \mathrm{Mg}$ and $\mathrm{Na}$ ) have patterns of gain and losses. This indicates a loss of base cations from the soil due to leaching. The positive strains are in some cases observed in especially profile 47 and 60 which are placed at lower elevation. Calcium and magnesium are very small amount in granitic rock. So very small amount addition of these elements can be reason of gain. The positive values are mainly due to the inflow of $\mathrm{Ca}$ and $\mathrm{Mg}$ rich water from higher area.

The positive strains or lower values are in some cases observed in surface horizons. The positive values are mainly due to the presence of organic matter that has a lower bulk density and lower concentrations of immobile element than mineral soil materials thus contributes to dilation ${ }^{57,58}$. The gains of sodium in surface horizons of profile are likely due to atmospheric contributions. The overall decrease in $\mathrm{K}$ content of the soils is also due to the weathering of $\mathrm{K}$-feldspars dominant mineral supplying potassium to the soils. Due to the absence of amphiboles, pyroxene and apatite $\mathrm{Na}$ and $\mathrm{K}$ loses must be principally explained by changes in the albite and orthoclase content. The leaching of the potassium, iron and magnesium can be explained by the dissolution of the micas and the transformation of the biotite into smectite. Calcium has slightly different behaviour. The net losses of $\mathrm{Ca}$ seem in many cases to be minor if compared to $\mathrm{Na}$ in most cases. Also $\mathrm{K}$ is rather sensitive to early weathering processes at our investigation sites and is removed in it's to about $47 \%$ of its initial content.

Magnesium is only weathered to a substantial amount (maximum 59.9\%) in the profile 49. Similar values $\mathrm{Mg}$ losses in the E horizon of podzols from 73 to $86 \%$ are also reported by Olsson and Melkerud ${ }^{59}$. The higher $\mathrm{Mg}$ losses at the profile 49 site. A weak accumulation of $\mathrm{Ca}, \mathrm{Mg}, \mathrm{Na}$ and $\mathrm{K}$ in the all horizons of profile 47 and 60 can be recorded, which indicates bioaccumulation, due to nutrient cycling. The profile 47 and 60 developed on the most covered area by different Pinus and Quercus forest (Pinus buritia te., Pinus pinea L., Pinus nigra, Quercus occifera, Quercus infectoria, Quercus cerris, Quercus libani, Cedrus libani, Abiescilicica) and brushwood. Dilatation of soils on profile 47 and 60 is also attributed to the bicycling of nutrients and organic matter, while soil collapse is due to the weathering and leaching of iron, aluminum and silica.
Mass transport data indicate that all profiles (except for profile 47 and 60) have a negative mass flux of Al. This indicates a loss of $\mathrm{Al}$ from the soil due to leaching. Obviously weathering rates of $\mathrm{Al}$ are much faster in the top soil than those observed over the whole profile. The differences indicate that $\mathrm{Al}$ is quickly removed from the top soil and partially reprecieped in the lover horizons and therefore account for the lover leaching rates there. Mass transport data indicate that all profiles have a negative mass flux of Fe. This indicates that some dissolved iron is leached from the profile. The iron and aluminum remaining in the profile are re-distributed from sand to sesquioxides and clay-size fractions and from less stable to more stable clay minerals.

The calculation of losses was not for all soil sequally successful. Some minor changes in the mineralogy (due to a slightly varying geology), such or aeolian additions might have led to some unexplained results (e.g. Table-3, positive values in the whole soil profile of the mass transfer function of bases in profile 47). For all other components, almost no difference could be seen between the mineralogical properties of parent materials. Thus, the variation of the state factor parent material ${ }^{60}$ is of minor importance. The influence of aeolian contribution is nonetheless overshadowed by minor in homogeneities in the geological substrate. The main differences may be also explained by differences climatic conditions resulted from of altitude, facing sites, topography, elevation gradient, slopes, temperature difference and the consequently different element leaching.

The CIA is based on the progressive removal of soluble cations (e.g. $\mathrm{Ca}, \mathrm{Na}$ and $\mathrm{K}$ ) from minerals during chemical weathering and reflects the proportion of primary and secondary minerals in the bulk sample. CIA represents the degree of alteration of feldspars to clay minerals in the course of hydrolytic weathering and indicates the relative content of clay minerals. Soils and sediments derived from intensely weathered rocks and containing residual clay minerals such as kaolinite and or unweathered upper crustal rocks have a CIA value of $50^{61}$. The studied soils have CIA values of 85-90. When CIA values are classified as little weathered (50-60), a little weathered (60-70), moderately weathered (70-80), highly weathered (80-90) and extremely weathered (90-100), it is seen that although all of the soils in the study field are classified into different parent materials and catena, they are all in the same class. As the change interval of CIA values between profiles is limited and in spite of some differences in the horizon array in these soils, which are in the same class and exposed to similar weathering processes, there occurred variations in the profile differentiations because of other factors. A similar trend was seen in the distribution of product index $(\mathrm{P})$ values. In soils, the $\mathrm{P}$ values decreased with weathering. The $\mathrm{P}$ values were close to each other in profiles in different catena, indicating similar and low weathering conditions.

Another way to study the degree of chemical weathering of the investigated soil profiles is to calculate the relative change of rare earth element concentration. The abundance of trace elements and rare earth elements in sediments has been employed to provide clues as to both sources and changes in 
sediments from weathering and sedimentary processes ${ }^{46}$. Some geochemical ratios were used to quantification of weathering degree of studied profiles. Normalized rare earth element patterns can reflect the degree of weathering of materials and this also applies to a lesser extent to the light rare earth element fraction. Cerium and Eu can occur in different oxidation states and often show greater fractionation relative to the other rare earth elements. The rare earth element concentrations are normalized relative to a chondritic reference standard to facilitate the comparison of rare earth element patterns between sites. In all profiles, Eu anomalies were negative and very close to each other. The similarity of the negative Eu anomalies and their values in profiles classified indifferent catena indicate the existence of low and similar weathering conditions. Fractionation of $\mathrm{Ce}$ is known to occur during weathering and sedimentary processes. In the initial stages, negative $\mathrm{Ce}$ anomalies are seen in weathering products such as secondary hydrous phosphates ${ }^{62}$ and positive $\mathrm{Ce}$ anomalies appear in intensely weathered lateritic profiles where soluble $\mathrm{Ce}^{3+}$ oxidizes to insoluble, thermodynamically stable $\mathrm{Ce}^{4+}$ and accumulates in secondary cerianite, $\mathrm{Ce}(\mathrm{IV}) \mathrm{O}_{2}{ }^{63}$. Like Eu/Eu ${ }^{*}$, Ce anomalies showed small differentiation between profiles. The homogenous and relatively small $\mathrm{Ce}$ anomaly of the studied soil samples $\left(0.88<\mathrm{Ce} / \mathrm{Ce}^{*}<1.14\right.$; Table- $)$ indicated that the chemical weathering they underwent was similar and not intensive. $\mathrm{La} / \mathrm{Lu}$ values were also used in the quantification of weathering as an indicator of clay sedimentation in soils. Generally the small and homogenous distribution of La/Lu values and the differentiation between horizons without a regularly increasing trend indicates that weathering intensity is low and similar, too. Another indicator of weathering in soils is the enrichment of heavy rare earth element (HREE) or light rare earth elements (LREE). Light rare earth element is closely related with clay amount and movement. Light rare earth element is largely kept in the clays. Concordantly, the $\mathrm{La}_{(\mathrm{N})} /$ $\mathrm{Yb}_{(\mathrm{N})}$ values, which are indicators of light rare earth element/ heavy rare earth element, were examined. In all profiles, the $\mathrm{La}_{(\mathrm{N})} / \mathrm{Yb}_{(\mathrm{N})}$ rates were very small and very close to each other except profile 47 and 60, showing a positive distribution in all of them. The very small values of $\mathrm{La}_{(\mathrm{N})} / \mathrm{Yb}_{(\mathrm{N})}$ rates in profile 47 and 60 is due to low clay content of these profiles. This homogenous distribution among profiles indicates that light rare earth element is similar in profiles and, thus, that they were exposed to similar leaching effects. On the other hand, the distribution of the $\mathrm{La}_{(\mathrm{N})} / \mathrm{Sm}_{(\mathrm{N})}$ rate is very homogenous, which is an indicator of middle rare earth elements. This case indicates that although profiles are developed indifferent catena, their weathering levels are similar. Weathering trends can also be demonstrated in a plot of Th against Th/U. With the enhancement of weathering intensity, the $\mathrm{Th} / \mathrm{U}$ ratios in weathering products increase above the upper crustal igneous values of 3.5 to $4.0^{64}$. The $\mathrm{Th} / \mathrm{U}$ showed a flat differentiation in studied profiles. The Th/U ratios ranged from 0.27 to1.94 in soils classified both as the granite and the gneiss profile. This slight differentiation in $\mathrm{Th} / \mathrm{U}$ ratios indicates similar weathering conditions in surface horizons in profiles.

Furthermore, the pedogenic activity is also shown by some physical and chemical properties which were similar in all profiles. Similar physico-chemical properties especially similarity of the clay content also indicates similar weathering conditions.

\section{Conclusion}

Features of pedogenic evolution were detected in mountain soils developed on two different catena from the Buldan horst which is located between the Büyük Menderes and Alasehir grabens (Western Turkey). For these purpose geochemical features, elemental mass-balance change, some physico-chemical properties were determined to compare the weathering rates of profiles. The weathering indices as well as CIA, P, some geochemical rates and other characteristics (physical, chemical, etc.) indicated some pedogenic evolution. These findings indicate that soils developed on granite and gneiss on two catena have similar pedochemical activity. Mass balance calculations indicate that in extensive mineral weathering resulted in significant leaching losses of $\mathrm{Si}$, major base cations and $\mathrm{Al}$ (particularly from upper horizons). The dominant processes identified with mass-balance analysis include desilication and loss of bases. This is primarily due to the weathering of biotite and K-feldspars and to a lesser degree quartz. Aluminum seems to exhibit a varying weathering behaviour, with higher rates in the topsoil and a rather linear release with respect to the whole soil profile. Gains and losses of the major soil forming elements ( $\mathrm{Si}, \mathrm{Al}$ and $\mathrm{Fe}$ ) were also quantified relative to mineral transformations. Iron and aluminum are being redistributed from the sand and silt-size fractions to secondary clay and sesquioxide fractions.

A very simple relationship between the site properties and elements losses could be found. Our results imply that the rate of elemental mass-balance changes is determined by factors influencing its leaching (altitude, facing sites, topography, elevation gradient, slopes). The results show that the site conditions of soil development have a much greater influence on elemental leaching and weathering than parent material in the soils studied.

Although the soils had similar weathering rates, the major factors determining soil genesis, classification, morphological properties and account of diagnostics horizons in this area appear to be the result of the topography causing erosion rather than climate and the nature of parent material affected by leaching regime and weathering rates.

\section{REFERENCES}

1. M. Ford Cochran and R.A. Berner, Chem. Geol., 132, 71 (1996)

2. R.A. Berner and M.F. Cochran, J. Sediment. Res., 68, 723 (1998).

3. M. Hornung, K.R. Bull, M. Cresser, J. Hall, S.J. Langan, P. Loveland and C. Smith, Environ. Pollut., 90, 301 (1995).

4. R.A. Berner, in eds.: A.F. White and S.L. Brantley, Chemical Weathering and its Effect on Atmospheric $\mathrm{CO}_{2}$ and Climate, Reviews in Mineralogy 31. Mineralogical Society of America, pp. 565-583 (1995).

5. L. Duan, J. Hao, S. Xie, Z. Zhou and X. Ye, Geoderma, 110, 205 (2002).

6. M.E. Hodson, S.J. Langan, F.M. Kennedy and D.C. Bain, Geoderma, 85, 1 (1998).

7. S.J. Langan, B. Reynolds and D.C. Bain, Geoderma, 69, 275 (1996).

8. H. Sverdrup and P. Warfvinge, Appl. Geochem., 8, 273 (1993).

9. J. Middelburg, C. Vanderweijden and J. Woittiez, Chem. Geol., 68, 253 (1988)

10. P.W. Birkeland, Soils and Geomorphology, Oxford University Press, New York, edn 3, p. 372 (1999). 
11. S.B. Feldman, L.W. Zelazny and J.C. Baker, Soil Sci. Soc. Am. J., 55, 1629 (1991).

12. R.C. Graham, B.E. Herbert and J.O. Ervin, Soil Sci. Soc. Am. J., 52, 738 (1988).

13. R.C. Graham, R.B. Daniels and S.W. Buol, Soil Sci. Soc. Am. J., 54, 1362 (1990).

14. T. Glade, Catena, 51, 297 (2003).

15. S.J. Sutton and J.B. Maynard, Can. J. Earth Sci., 29, 432 (1992).

16. O.A. Chadwick and J. Chorover, Geoderma, 100, 321 (2001).

17. S. Cornu, Pedogeneses d'hier et d'aujourd'hui, Thesis. Université d'Orléans, pp. 81 (2005).

18. G.H. Brimhall and W.E. Dietrich, Geochim. Cosmochim. Acta, 51, 567 (1987).

19. G.H. Brimhall, O.A. Chadwick, C.J. Lewis, W. Compston, I.S. Williams, K.J. Danti, W.E. Dietrich, M.E. Power, D. Hendricks and J. Bratt, Science, 255, 695 (1992).

20. O.A. Chadwick, G.H. Brimhall and D.M. Hendricks, Geomorphology, 3, 369 (1990).

21. S.M. McLennan, W.B. Nance and S.R. Taylor, Geochim. Cosmochim. Acta, 44, 1833 (1980).

22. S.R. Taylor, S.M. McLennan, R.L. Armstrong and J. Tarney, Philos. Trans. R. Soc. A, 301, 381 (1981).

23. M.R. Bhatia, J. Geol., 91, 611 (1983).

24. S.R. Taylor and S.M. McLennan, The Continental Crust: Its Composition and Evolution, Oxford, Blackwells, London (1985).

25. D.J. Wronkiewicz and K.C. Condie, Geochim. Cosmochim. Acta, 51, 2401 (1987).

26. R.L. Cullers, Lithos, 21, 301 (1988).

27. H.W. Nesbitt and G.M. Young, Geochim. Cosmochim. Acta, 48, 1523 (1984)

28. H.W. Nesbitt and G.M. Young, J. Geol., 97, 129 (1989).

29. J.I. Garver and J.T. Scott, Geol. Soc. Am. Bull., 107, 440 (1995).

30. C.M. Fedo, K.A. Eriksson and E.J. Krogstad, Geochim. Cosmochim. Acta, 60, 1751 (1996).

31. R. April, R. Newton and L.T. Coles, Geol. Soc. Am. Bull., 97, 1232 (1986).

32. U. Eggenberger, Ph.D. Thesis, Mineral Weathering in Soils: Experiments, Field Studies, and Modeling, University of Bern, pp. 198 (1995).

33. S.J. Langley-Turnbaugh and J.G. Bockheim, Geoderma, 84, 265 (1998).

34. A. Nieuwenhuyse and N. van Breemen, J. Soil Sci. Soc. Am., 61, 1450 (1997).

35. A.F. White, in eds.: A.F. White and S.L. Brantley, Chemical Weathering Rates of Silicate Minerals in Soils, Chemical Weathering Rates of Silicate Minerals, Mineralogical Society of America Special Publication, vol. 31, Mineralogical Society of America, Washington D.C., pp. 407-461, (1995).

36. M. Egli and P. Fitze, Soil Sci., 165, 437 (2000).

37. N.H. Oh and D.D. Richter, Geoderma, 126, 5 (2005).

38. E.G. Green, W.E. Dietrich and J.F. Banfield, Earth Planet. Sci. Lett. 242, 155 (2006)
39. S. Cornu, Y. Lucas, E. Lebon, J.P. Ambrosi, F. Luizão, J. Rouiller, M. Bonnay and C. Neal, Geoderma, 91, 281 (1999).

40. D.J. Merritts, O.A. Chadwick, D.M. Hendricks, G.H. Brimhall and C.J. Lewis, Geol. Soc. Am. Bull., 104, 1456 (1992).

41. G.H. Brimhall, L. Christopher J, C. Ford, J. Bratt, G. Taylor and O. Warin, Geoderma, 51, 51 (1991).

42. C.E. Marshall and J.F. Haseman, Soil Sci. Soc. Am. Proc., 7, 448 (1943).

43. J.W. Harden, Geoderma, 43, 179 (1988).

44. L. Harnois, Sediment. Geol., 55, 319 (1988).

45. H.W. Nesbitt and G.M. Young, Nature, 299, 715 (1982).

46. P. Reiche, A Survey of Weathering Processes and Products, University of New Mexico Press, Albuquerque (1950).

47. S.M. McLennan, S. Hemming, D.K. McDaniel and G.N. Hanson, Geol. Soc. Am., 284, 21 (1993).

48. S.R. Taylor and S.M. McLennan, The Continental Crust: Its Composition and Evolution, Blackwell, London, pp. 311 (1985).

49. H. Senol, Ph.D. Thesis, Physical, Chemical and Mineralogical Properties of Common Great Soil Groups in the Lakes District of Turkey, Suleyman Demirel University Graduate School of Applied and Natural Sciences, Soil Science and Plant Nutrition Department, pp. 310 (2012).

50. Soil Survey Staff, Soil Taxonomy, A Basic System of Soil Classification for Making and Interpreting Soil Surveys, Agriculture Handbook, edn. 2, Vol. 436, US Government Printing Office, Washington DC, p. 869 (1999).

51. K. Koçak and H. Senol, Cumhuriyet University, Geological Engineering 30 Years Symposium, p. 69 (2012).

52. L.E. Allison and C.D. Moodie, in eds.: C.A. Black et al., Carbonate, Methods of Soil Analysis, Part 2, Agron. Monogr. 9, ASA, CSSA and SSSA, Madison, WI, edn. 2, pp. 1379-1400 (1965).

53. D.W. Nelson and L.E. Sommers, in ed.: A.L. Page, Total Carbon, Organic Carbon and Organic Matter, Methods of Soil Analysis, Part 2, Agron. Monogr. 9, ASA and SSSA, Madison, WI, edn. 2, pp. 539-579 (1982).

54. USDA, Diagnosis and Improvement of Saline and Alkali Soils, US Government Printing Office, Washington, DC., USA (1954).

55. G.J. Bouyoucos, Agron. J., 43, 434 (1951).

56. T.T. Chao and R.F. Sanzolone, J. Geochem. Explor., 44, 65 (1992).

57. H.H. Ozaytekin, H.H. Mutlu and M. Dedeoglu, J. Afr. Earth Sci., 76, 66 (2012).

58. M. Egli, P. Fitze and A. Mirabella, Catena, 45, 19 (2001).

59. M.T. Olsson and P.-A. Melkerud, Geoderma, 94, 149 (2000).

60. H. Jenny, The Soil Resource, Springer, New York, p. 281 (1980).

61. C.M. Fedo, H. Wayne Nesbitt and G.M. Young, Geology, 23, 921 (1995).

62. J.-J. Braun, J. Viers, B. Dupré, M. Polve, J. Ndam and J.-P. Muller, Geochim. Cosmochim. Acta, 62, 273 (1998).

63. Y. Pan and M.R. Stauffer, Am. Min., 85, 898 (2000).

64. S.M. McLennan, in eds.; T.J. Ahrens, Sediments and Oils: Chemistry and Abundances, Rock Physics and Phase Relations: A Handbook of Physical Constants, vol. 3. American Geophysical Union Reference Shelf, pp. 8-19 (1995). 